\section{Monitoring of volatile organic compounds in ambient air of Taldykorgan, Kazakhstan}

${ }^{1}$ Serik L., ${ }^{2}$ Ibragimova O.P., ${ }^{3}$ Ussenova G.K., ${ }^{2}$ Baimatova N.Kh.*

${ }^{1}$ School of Sciences and Humanities, Nazarbayev University Nur-Sultan, Kazakhstan ${ }^{2} \mathrm{Al}$-Farabi Kazakh National University, Center of Physicochemical methods of research and analysis, Almaty, Kazakhstan ${ }^{3}$ Nazarbayev Intellectual School of Physics and Mathematics, Almaty, Kazakhstan *E-mail: baimatova@cfhma.k
The pollution of ambient air is one of the main sources of risk to human health in the world. There is a direct relationship between the level of air pollution and risk of the development of cancer, cardiovascular, respiratory and other diseases. Benzene, toluene, ethylbenzene and $o$-xylene (BTEX) are one of the most toxic volatile organic compounds. The aim of this study was to quantify BTEX in air of Taldykorgan, Kazakhstan using solid-phase microextraction followed by gas chromatography with mass-spectrometric detection. In different sampling seasons, average concentrations of four BTEX analytes varied from 7.5 to $27 \mu \mathrm{g} / \mathrm{m}^{3}$, from 15 to $250 \mathrm{\mu g} / \mathrm{m}^{3}$, from 2.4 to $12.8 \mu \mathrm{g} / \mathrm{m}^{3}$ and from 2.6 to $21 \mathrm{\mu g} / \mathrm{m}^{3}$, respectively. The highest concentrations of TEX were detected in autumn, while the highest concentrations of benzene were observed in winter. Toluene-to-benzene ratios in almost all measurements were above 1 indicating that the traffic emissions are the main source of air pollution with BTEX.

Keywords: SPME; GC-MS; BTEX; air pollution; air analysis; Taldykorgan.

\section{Қазақстан, Талдықорған қаласынын ауасындағы ұшқыш органикалық қосылыстардын мониторингі}

${ }^{1}$ Серик Л., ${ }^{2}$ Ирагимова О.П.,

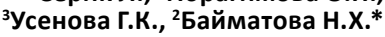

${ }^{1}$ Назарбаев Университетінің жаратылыстану, әлеуметтік және гуманитарлық ғылымдар мектебі Нұр-Сұлтан, Казахстан

гәл-Фараби атындағы Қазақ ұлттық университеті, Физика-химиялық зерттеу әдістері орталығы, Алматы, Қазақстан

${ }^{3}$ Алматы қаласындағы физикаматематика бағытындағы Назарбаев Зияткерлік мектебі, Алматы, Қазақстан *E-mail: baimatova@cfhma.kz
Бүкіл әлемде атмосфералық ауаның ластануы адамдардың денсаулығы үшін негізгі қауіп көзі болып саналады. Ауаның ластану деңгейі мен онкологиялық, жүрек-қан тамырларының, респираторлық және басқа да аурулардың пайда болу қаупі арасында тікелей тәуелділік туғызады. Ең улы ұшқыш органикалық қосылыстардың бірі-бензол, толуол, этилбензол және о-ксилол (БТЭК). Бұл жұмыстың мақсаты масс-спектрометриялық детекторы бар газды хроматография және қатты фазалы микроэкстракция әдісімен Талдықорған қаласының ауасындағы БТЭК анықтау және идентификациялау болып табылады. Сынама іріктеудің әртүрлі маусымдарында БТЭК орташа концентрацияларь тиісінше 7,5-ден 27-ге дейін, 15-тен 250-ге дейін, 2,4-тан 12,8-ге дейін және 2,6-тан 21 мкг/ $\mathrm{m}^{3}$-қа дейін өзгеріп отырды. ТЭК ең жоғары концентрациясы күзгі кезеңде табылды, ал бензолдың ең жоғары концентрациясы қыста байқалды. Толуолдың бензолға қатынась барлық өлшемдерде 1-ден жоғары болды, бұл БТЭК ауаны ластаудың негізгі көзі автокөлік шығарындылары болып табылатынын көрсетеді.

Түйін сөздер: ҚФМЭ; ГХ-МС; БТЭК; ауаның ластануы; ауа талдауы; Талдықорған.

\section{Мониторинг летучих органических соединений в воздухе города Талдыкорган, Казахстан}

${ }^{1}$ Серик Л., ${ }^{2}$ Ирагимова О.П., ${ }^{3}$ Усенова Г.К., 'Байматова Н.Х.*

${ }^{1}$ Школа естественных, гуманитарных и социальных наук, Назарбаев Университет Нур-Султан, Казахстан

${ }^{2}$ Казахский национальный университет им. аль-Фараби, Центр физикохимических методов исследования и анализа, Алматы, Казахстан

${ }^{3}$ Назарбаев Интеллектуальная Школа физико-математического направления, Алматы, Казахстан *E-mail: baimatova@cfhma.kz
Во всем мире загрязнение атмосферного воздуха считается одним из основных источников риска для здоровья людей. Существует прямая зависимость между уровнем загрязнения воздуха и риском возникновения онкологических, сердечно-сосудистых, респираторных и других заболеваний. Одними из самых токсичных летчуих органических соединений (ЛОС) являются бензол, толуол, этилбензол и о-ксилол (БТЭК). Целью данной работы было установить концентрации БТЭК в воздухе города Талдыкорган, Казахстан методом твердофазной микроэкстракции в сочетании с газовой хроматомасс-спектрометрией. В разные сезоны пробоотбора средние концентрации БТЭК

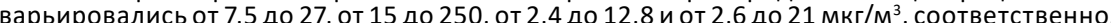
Максимальные концентрации ТЭК были обнаружены в осенний период, в то время как самые высокие концентрации бензола наблюдались зимой. Отношение толуола к бензолу почти во всех измерениях было выше 1, что указывает на то, что основным источником загрязнения воздуха БТЭК является выбросы автотранспортных средств.

Ключевые слова: ТФМЭ; ГХ-МС; БТЭК; загрязнение воздуха; анализ воздуха Талдыкорган. 


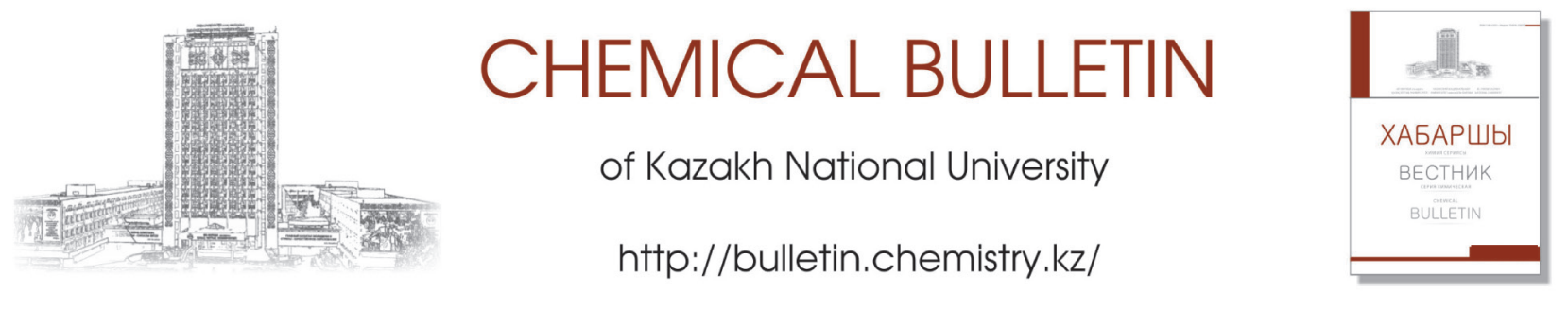

\title{
Monitoring of volatile organic compounds in ambient air of Taldykorgan, Kazakhstan
}

\author{
${ }^{1}$ Serik L. (D), ${ }^{2}$ Ibragimova O.P. (D), ${ }^{3}$ Ussenova G.K. (D), ${ }^{2}$ Baimatova N.Kh.* (i) \\ ${ }^{1}$ School of Sciences and Humanities, Nazarbayev University, Nur-Sultan, Kazakhstan \\ ${ }^{2} \mathrm{Al}$-Farabi Kazakh National University, Center of Physicochemical methods of research and analysis, Almaty, Kazakhstan \\ ${ }^{3}$ Nazarbayev Intellectual School of Physics and Mathematics, Almaty, Kazakhstan \\ *E-mail: baimatova@cfhma.kz
}

\section{Introduction}

Fast and uncontrolled population growth, increase of energy consumption and private transportation lead to a serious problem of air pollution in most cities around the world [1]. Air pollution leads to ecosystem failure and creates huge economic and social harm to the society. WHO reported that in 2016, about 4.2 million of premature deaths were caused by ambient air pollution [1]. 91\% of deaths were in low- or middle-income countries [1]. Ambient and indoor air pollution causes the highest health risks around the world.

One of the most important stages in the activities aimed at decreasing the ambient air pollution is its monitoring [2]. It allows predicting the trends in change of concentrations of contaminants, estimating an efficiency of anti-pollution activities, identification of new dangerous contaminants and key, most dangerous and illegal pollution sources.

One of the most dangerous group of air pollutants is volatile organic compounds (VOCs) which are released into the atmosphere due to biogenic and anthropogenic activity, as well as in the result of the photolysis of gases in the air [2]. The main sources of VOCs in the air are exhaust gases of vehicles, power plants, industry, construction as well as the emissions from household activities: cigarette smoke, paints, aerosols and cleaning products [3]. Special attention is paid to benzene, toluene, ethylbenzene and xylenes (BTEX) due to their high toxicity. Many countries regulate and mandate monitoring BTEX concentrations in ambient air [4].

The problem of air pollution exists not only in large cities, but also in small ones such as Taldykorgan, Kazakhstan. Taldykorgan is the center of Almaty region and a neighboring city with Almaty. For several decades, it was considered one of the most environmentally friendly cities in Kazakhstan, as there have never been large industrial plants. Nowadays, the air quality in Taldykorgan has deteriorated. This can be caused by the intensive expansion of the city, the construction of new residential areas and, accordingly, the increase in the number of vehicles and amount of the heating systems in the cold seasons. Taldykorgan does not have access to the gas pipeline. As a result, coal is the main fuel for obtaining electricity and heat generation in the city.

No data on the concentrations of the most common and dangerous pollutants, including BTEX, in air of Taldykorgan are available. For BTEX, it can be caused by a complexity of standard analytical methods [5]. Currently, three main approaches are most widely used for determination of BTEX in air [6-11]:

1. Air sampling in containers or canisters with different volume [7-10]. Containers for sampling are made from materials such as Teflon, glass or stainless steel. To concentrate the analytes, the sampled air is passed through sorbent tubes followed by desorption in a thermal desorption unit (TDU) connected to the inlet of gas chromatograph.

2. Passing of air samples through a suitable VOCs-retaining sorbent, followed by transferring the analytes to the inlet of gas chromatograph using thermal desorption unit [10];

3. Continuous analysis of VOCs concentrations using mobile monitoring stations and portable devices $[11,12]$.

The disadvantages of the first two approaches are:

- the need for cleaning of containers and sorption tubes with high purity helium;

- the need for additional thermal desorption unit for desorption of analytes;

- thermal desorption of analytes from sorption tubes and its transfer to a gas chromatograph is a slow process, which causes wide and poorly separated peaks observed in chromatograms. 
Monitoring of volatile organic compounds in ambient air...

For achieving proper accuracy, the third approach requires costly equipment, which is unavailable in Kazakhstan.

All these factors result in the absence of information from the official sources about air pollution with BTEX in Kazakhstan although the required equipment is available in responsible laboratories.

Solid-phase microextraction is one of the most perspective methods for sampling and quantification of VOCs in air developed by Arthur and Pawliszyn from Waterloo University (Canada) in 1989 [13-15]. SPME is based on a sorption of analytes onto a polymeric coating followed by a desorption in a GC inlet. SPME is very efficient and popular for screening of VOCs in air. Available commercial fibers allow detecting all VOCs or a narrow group of analytes depending on their polarity and volatility. Using SPME in combination with gas chromatography mass-spectrometry (GC-MS), Carlsen et al. identified more than 100 VOCs in the air of Almaty [16]. Baimatova et al. [17] developed a very simple and accurate method for quantification of BTEX in ambient air and applied it in Almaty, Kazakhstan.

The objective of this research was to determine the levels of BTEX in ambient air of Taldykorgan in different seasons during 2018-2019 by SPME-GC-MS using the method developed by Baimatova et al. [17].

\section{Experiment}

\subsection{Air sampling sites}

Sampling was conducted at three sites located in different districts of Taldykorgan: Karatal, Center and the $2^{\text {nd }}$ Microdistrict. Sampling sites (A1, A2, A3) were chosen in different parts of the city for determination of mean BTEX concentrations. Sampling sites were located close to the main roadways of the city, but at a distance of more than $15 \mathrm{~m}$ from road - Almaty highway, Zhansygurov street and Kabanbay Batyr street (Table 1). Meteorological parameters such as temperature, wind speed and humidity (Table 2) were taken from publicly available database Gismeteo.

Table 1 - Description of sampling sites

\begin{tabular}{ccl}
\hline $\begin{array}{c}\text { Sampling } \\
\text { site }\end{array}$ & $\begin{array}{c}\text { Crossroad } \\
\text { (coordinates) }\end{array}$ & Objects within a radius of $200 \mathrm{~m}$ \\
\hline A1 & $\begin{array}{c}\text { Rakishev- } \\
\text { Kablisa-Zhyrau } \\
\left(45^{\circ} 00^{\prime} 31.6^{\prime \prime} \mathrm{N},\right. \\
\left.78^{\circ} 20^{\prime} 49.1^{\prime \prime} \mathrm{E}\right)\end{array}$ & $\begin{array}{l}\text { Almaty highway, new residential } \\
\text { microdistricts, university, gas } \\
\text { station }\end{array}$ \\
& $\begin{array}{c}\text { Shevchenko } \\
\text { Kabanbay batyr } \\
\left(45^{\circ} 01^{\prime} 13.3^{\prime \prime} \mathrm{N},\right. \\
\left.78^{\circ} 22^{\prime} 32.6^{\prime \prime} \mathrm{E}\right)\end{array}$ & $\begin{array}{l}\text { Low-rise buildings, shopping } \\
\text { complexes Karagash, Shagan, } \\
\text { Eurasia, bazaar }\end{array}$ \\
A2 & $\begin{array}{l}\text { Zhansygurov } \\
\text { - Naberezhnaya } \\
\left(45^{\circ} 00^{\prime} 36.7^{\prime \prime} \mathrm{N},\right. \\
\left.78^{\circ} 24^{\prime} 10.3^{\prime \prime} \mathrm{E}\right)\end{array}$ & $\begin{array}{l}\text { Residential buildings, shopping } \\
\text { and entertainment complex City } \\
\text { Plus, Nazarbaev Intellectual } \\
\text { School, school No. 9, Karatal } \\
\text { river, riverside }\end{array}$ \\
& &
\end{tabular}

Table $\mathbf{2}$ - Weather conditions on sampling days

\begin{tabular}{cccccc}
\hline $\begin{array}{c}\text { Sampling } \\
\text { date }\end{array}$ & $\begin{array}{c}\text { Air tempe- } \\
\text { rature, }{ }^{\circ} \mathrm{C}\end{array}$ & $\begin{array}{c}\text { Weather } \\
\text { conditions }\end{array}$ & $\begin{array}{c}\text { Wind } \\
\text { velocity, } \\
\mathrm{m} / \mathrm{s}\end{array}$ & $\begin{array}{c}\text { Pressure, } \\
\mathrm{mmHg}\end{array}$ & $\begin{array}{c}\text { Humi- } \\
\text { dity, } \%\end{array}$ \\
\hline $10 / 3 / 2018$ & 13 & rainy & 1 & 713 & 77 \\
$12 / 4 / 2018$ & 15 & sunny & 6 & 715 & 53 \\
$14 / 4 / 2018$ & 24 & cloudy & 3 & 705 & 60 \\
$12 / 07 / 2018$ & 33 & sunny & 5,8 & 714 & 25 \\
$14 / 07 / 2018$ & 32 & rainy & 5 & 702 & 38 \\
$16 / 07 / 2018$ & 34 & cloudy & 0 & 701 & 64 \\
$16 / 10 / 2018$ & 0 & snow & 0 & 716 & 94 \\
$18 / 10 / 2018$ & 5 & sunny & 2 & 713 & 39 \\
$20 / 10 / 2018$ & 12 & cloudy & 3 & 719 & 62 \\
$14 / 01 / 2019$ & -13 & sunny & 2 & 710 & 72 \\
$16 / 01 / 2019$ & -3 & cloudy & 3 & 715 & 77 \\
$18 / 01 / 2019$ & -10 & sunny & 0 & 709 & 91 \\
\hline
\end{tabular}

Sampling was conducted four times a year between 5 PM and 6 PM on April 10, 12 and 14; July 12, 14 and 16; October 16, 18 and 20, 2018 and January 14, 16 and 18, 2019. Nine air samples were collected per one sampling day and 27 samples per season. In Almaty sampling was conducted at six different districts between 8 and 9 AM and 8 and 9 PM on April 3, 5 and 7 (Table 3). 36 air samples were collected per day and 108 samples in total.

Table 3 - Sampling sites in Almaty

\begin{tabular}{|c|c|c|}
\hline $\begin{array}{l}\text { Sampling } \\
\text { site }\end{array}$ & $\begin{array}{l}\text { Crossroad } \\
\text { (coordinates) }\end{array}$ & $\begin{array}{l}\text { Height, } \\
\mathrm{m}\end{array}$ \\
\hline S1 & $\begin{array}{l}\text { Radostovets st. - al-Farabi av. } \\
\left(\mathrm{N} 43^{\circ} 12.007^{\prime}, \mathrm{E} 76^{\circ} 53.774^{\prime}\right)\end{array}$ & 978 \\
\hline S2 & $\begin{array}{l}\text { Mendikulov st. - al-Farabi av. } \\
\left.\text { (N43 } 13.654^{\prime}, \text { E76 } 57.252^{\prime}\right)\end{array}$ & 944 \\
\hline S3 & $\begin{array}{c}\text { Nauryzbay Batyr st. - Raiymbek av. } \\
\left(\mathrm{N} 43^{\circ} 16.099^{\prime}, \mathrm{E} 76^{\circ} 56.062^{\prime}\right)\end{array}$ & 764 \\
\hline S4 & $\begin{array}{l}\text { Papanin st. - Suyunbay av. } \\
\left(\mathrm{N} 43^{\circ} 19.095^{\prime}, \mathrm{E} 76^{\circ} 57.781^{\prime}\right)\end{array}$ & 700 \\
\hline S5 & $\begin{array}{l}\text { Raiymbek av. - Akhrimenko st. } \\
\left(\mathrm{N} 43^{\circ} 14.950^{\prime}, \mathrm{E}^{\circ} 50.844^{\prime}\right)\end{array}$ & 770 \\
\hline S6 & $\begin{array}{l}\text { Shevchenko st. - Gagarin av. } \\
\left(\mathrm{N} 43^{\circ} 14.612^{\prime}, \mathrm{E} 76^{\circ} 53.586^{\prime}\right)\end{array}$ & 803 \\
\hline
\end{tabular}

\subsection{Air sampling using SPME}

Air sampling was conducted as described by Baimatova et al. [17]. Ambient air samples were collected into $20-\mathrm{mL}$ crimptop vials (Agilent, USA) in triplicates by opening vial to air and shaking of $\sim 60 \mathrm{sec}$ to increase air exchange and sealed with aluminum caps with polytetrafluoroethylene/silicone septa (Agilent, USA). Vials were transported to the laboratory in 1-L glass jars. Prior to sampling all vials and caps were washed by 
Table 4 - Results of calibration using SPME and GC-MS

\begin{tabular}{lccccc}
\hline \multirow{2}{*}{ Analyte } & $\begin{array}{c}\text { Retention time, } \\
\text { min }\end{array}$ & $\begin{array}{c}\text { Calibration range, } \\
\mu \mathrm{g} / \mathrm{m}^{3}\end{array}$ & & & \multicolumn{2}{c}{$R^{2}$} \\
\cline { 5 - 6 } Benzene & 7.7 & $20-200$ & 0.9603 & Summer & Autumn \\
Toluene & 9.3 & $20-200$ & 0.9947 & 0.9906 & 0.9780 \\
Ethylbenzene & 10.6 & $2-20$ & 0.9905 & 0.9931 & 0.9988 \\
$o-$-Xylene & 11.7 & $2-20$ & 0.9922 & 0.9976 & 0.9956 \\
\hline
\end{tabular}

distilled water and conditioned at $160^{\circ} \mathrm{C}$ during $4 \mathrm{~h}$. Vials with sampled air were placed on Combi-PAL tray (CTC Analytics AG, Switzerland) for further GC-MS analysis. The analytes were extracted from vials by exposed $85 \mu \mathrm{m}$ Carboxen/ polydimethylsiloxane (Car/PDMS) SPME fiber at room temperature $\left(\mathrm{T}=22^{\circ} \mathrm{C}\right)$ for $7 \mathrm{~min}$.

\subsection{Air sample analyses with GC-MS}

Analytes were desorbed from a fiber in the split/splitless inlet of 7890A/5975C GC-MS system (Agilent, Santa Clara, USA). Inlet was equipped with a $0.75 \mathrm{~mm}$ ID SPME liner (Supelco, USA) operating in splitless mode at $250^{\circ} \mathrm{C}$. Separation of BTEX was conducted in a $60 \mathrm{~m} \times 0.25 \mathrm{~mm}$ DB-WAXetr (Agilent, USA) column with $0.50 \mu \mathrm{m}$ film thickness at a constant $(1 \mathrm{~mL} / \mathrm{min})$ helium (>99.995\%, Orenburg-Tehgas, Orenburg, Russia) flow. Temperatures of MS interface, quadrupole and ion source were 250,150 and $230^{\circ} \mathrm{C}$, respectively. Oven temperature was programmed from $40^{\circ} \mathrm{C}$ (held for $1 \mathrm{~min}$ ) to $160^{\circ} \mathrm{C}$ (held for $2 \mathrm{~min}$ ) with a heating rate of $10^{\circ} \mathrm{C} / \mathrm{min}$. Total $\mathrm{GC}$ run time was $15 \mathrm{~min}$. MS detector was running in selected ion monitoring (SIM) mode for better sensitivity at $m / z$ 78, 91, 106 and 106 amu for BTEX, respectively.

\subsection{Calibration and quantification of BTEX}

Benzene (99.8\%) and toluene (99.8\%) were obtained from "EKOS-1" LLP (Moscow, Russia). Ethylbenzene (99.0\%) and o-xylene (99.0\%) were purchased from Sigma-Aldrich (St. Louis, $\mathrm{MO}$, USA). All solutions were prepared in methanol ( $\geq 99.9 \%)$ purchased from Sigma-Aldrich (St. Louis, MO, USA).

Calibration was conducted using standard addition method. Standard solutions $(1.00 \mu \mathrm{L})$ were injected into $20-\mathrm{mL}$ vials. Concentrations of benzene, toluene and ethylbenzene, $o$-xylene were different due to their different background concentrations in ambient air. Addition concentrations of BT were $20,50,100$ and $200 \mu \mathrm{g} / \mathrm{m}^{3}$; and 2, 5, 10 and $20 \mu \mathrm{g} / \mathrm{m}^{3}$ for EX. Obtained calibration plots were linear $\left(R^{2}>0.99\right)$. Calibration results are presented in Table 4 . Mean relative standard deviations (RSD) ranged from 1 to $5 \%$.

\section{Results and discussion}

\subsection{General characterization of data}

Chromatograms obtained for air samples provided a proper separation (Figure 1). Signal-to-noise ratios were

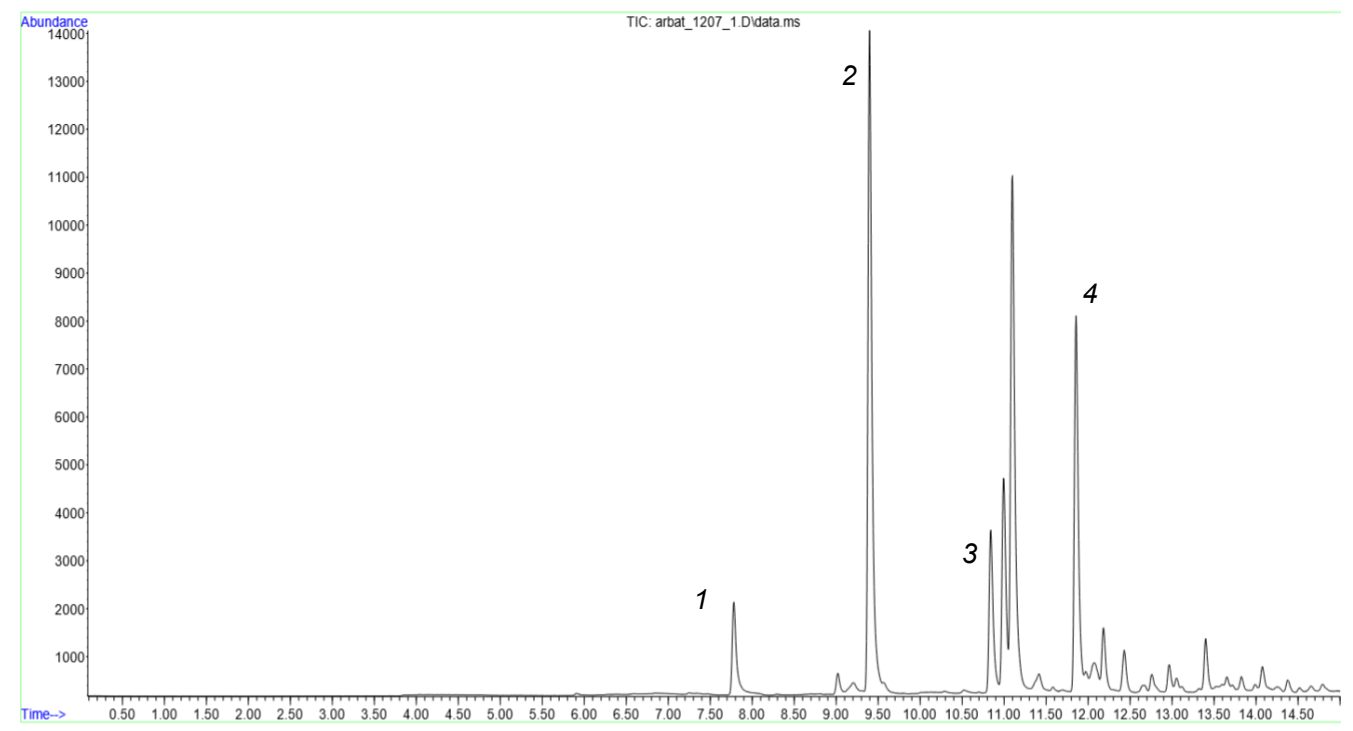

1 - benzene, 2 - toluene, 3 - ethylbenzene, 4 -o-xylene

Figure 1 - Chromatogram of air sample at sampling point A2 at 5 PM on July 12, 2018 
higher than 15:1 for all analytes. Mean concentrations of BTEX were calculated for all 27 air samples in Taldykorgan in each sampling period (Tables 5 and 6). RSDs of concentrations at three sampling sites at one sampling day did not exceed $25 \%$ in the most cases. The greatest RSDs between sampling sites were observed in winter ( $55 \%$ for toluene at third sampling day), which can be explained by random factors such as a car passing close to sampling site or a smoking person nearby. RSDs of most replicates were in the range $\pm 10 \%$. During entire sampling period, only 14 outliers were found $(<11 \%$ from total samples), most probably, caused by damage of vials and subsequent leakage of analytes. Thus, the previously developed method [17] is simple, accurate, reproducible and can be applied for air monitoring in different cities.

\subsection{Difference between districts}

Concentrations of BTEX were different at three districts of Taldykorgan (Karatal, Center and the $2^{\text {nd }}$ microdistrict) (Figure 2). The lowest concentrations of BTEX were detected in Karatal district while the highest - close to Almaty highway in $2^{\text {nd }}$ Microdistrict. Possible reason is that Karatal district is

Table 5 - Mean concentrations of BTEX in air of Taldykorgan in spring and summer, 2018

\begin{tabular}{|c|c|c|c|c|c|c|c|c|c|}
\hline & & \multicolumn{8}{|c|}{ Concentration $\pm \mathrm{SD}\left(\mu \mathrm{g} / \mathrm{m}^{3}\right)$} \\
\hline \multicolumn{2}{|c|}{ Sampling season } & \multicolumn{3}{|c|}{ Spring 2018} & \multirow{2}{*}{ Mean } & \multicolumn{3}{|c|}{ Summer 2018} & \multirow{2}{*}{ Mean } \\
\hline \multicolumn{2}{|c|}{ Sampling date } & $10 / 04$ & $12 / 04$ & $14 / 04$ & & $12 / 07$ & $14 / 07$ & $16 / 07$ & \\
\hline & Mean & $7 \pm 3$ & $13 \pm 5$ & $10 \pm 4$ & & $6.1 \pm 1.3$ & $7.3 \pm 0.5$ & $9.1 \pm 0.5$ & \\
\hline \multirow[t]{3}{*}{ Benzene } & Max & 11 & 18 & 14 & $10 \pm 4$ & 7.2 & 21.3 & 11.5 & $7.5 \pm 0.7$ \\
\hline & Min & 4 & 9 & 7 & & 5.4 & 3.5 & 7.6 & \\
\hline & Mean & $14 \pm 6$ & $20 \pm 10$ & $17 \pm 4$ & & $13.1 \pm 1.4$ & $15.1 \pm 1.4$ & $17.7 \pm 3.1$ & \\
\hline \multirow[t]{3}{*}{ Toluene } & Max & 20 & 31 & 22 & $17 \pm 7$ & 16.3 & 32.1 & 22.3 & $15.3 \pm 1.9$ \\
\hline & Min & 9 & 10 & 15 & & 11.4 & 13.2 & 14.1 & \\
\hline & Mean & $3.0 \pm 0.9$ & $3.5 \pm 1.1$ & $2.5 \pm 0.4$ & & $1.9 \pm 0.4$ & $2.4 \pm 1.1$ & $2.7 \pm 0.8$ & \\
\hline \multirow[t]{3}{*}{ Ethylbenzene } & Max & 4.0 & 4.7 & 2.8 & $3.0 \pm 0.8$ & 2.3 & 4.1 & 3.6 & $2.4 \pm 0.9$ \\
\hline & Min & 2.4 & 2.9 & 2.1 & & 1.5 & 1.4 & 2.1 & \\
\hline & Mean & $1.8 \pm 0.3$ & $3.3 \pm 0.8$ & $2.7 \pm 0.7$ & & $4.8 \pm 1.0$ & $7 \pm 3$ & $5.7 \pm 1.5$ & \\
\hline \multirow[t]{2}{*}{ o-Xylene } & Max & 2.0 & 4.3 & 3.1 & $2.6 \pm 0.6$ & 5.8 & 11 & 7.5 & $6 \pm 2$ \\
\hline & Min & 1.4 & 2.8 & 1.9 & & 3.8 & 4 & 4.7 & \\
\hline
\end{tabular}

Table 6 - Mean concentrations of BTEX in air of Taldykorgan in autumn 2018 and winter 2018-2019

\begin{tabular}{|c|c|c|c|c|c|c|c|c|c|}
\hline & & \multicolumn{8}{|c|}{ Concentration $\pm \mathrm{SD}\left(\mu \mathrm{g} / \mathrm{m}^{3}\right)$} \\
\hline \multicolumn{2}{|c|}{ Sampling season } & \multicolumn{3}{|c|}{ Autumn 2018} & \multirow{2}{*}{ Mean } & \multicolumn{3}{|c|}{ Winter 2018-2019 } & \multirow{2}{*}{ Mean } \\
\hline \multicolumn{2}{|c|}{ Sampling date } & $16 / 10$ & $18 / 10$ & $20 / 10$ & & $14 / 01$ & $16 / 01$ & $18 / 01$ & \\
\hline \multirow{3}{*}{ Benzene } & Mean & $39 \pm 8$ & $15.2 \pm 0.4$ & $8.4 \pm 1.1$ & & $45 \pm 25$ & $20 \pm 2$ & $17.4 \pm 1.4$ & \\
\hline & Max & 47 & 15.7 & 9.4 & $21 \pm 3$ & 70 & 21 & 18.2 & $27 \pm 9$ \\
\hline & Min & 30 & 14.8 & 7.2 & & 31 & 17 & 15.9 & \\
\hline \multirow{3}{*}{ Toluene } & Mean & $530 \pm 40$ & $160 \pm 30$ & $65 \pm 9$ & & $50 \pm 20$ & $39 \pm 13$ & $24 \pm 13$ & \\
\hline & Max & 810 & 230 & 74 & $250 \pm 30$ & 80 & 53 & 38 & $38 \pm 16$ \\
\hline & Min & 370 & 120 & 57 & & 35 & 30 & 13 & \\
\hline \multirow{3}{*}{ Ethylbenzene } & Mean & $27 \pm 4$ & $7.5 \pm 1.0$ & $4.1 \pm 0.6$ & & $3.9 \pm 0.9$ & $2.6 \pm 0.4$ & $2.1 \pm 0.3$ & \\
\hline & Max & 44 & 8.5 & 4.8 & $13 \pm 6$ & 4.6 & 2.8 & 2.5 & $2.9 \pm 0.5$ \\
\hline & Min & 15 & 6.6 & 3.7 & & 2.9 & 2.2 & 1.8 & \\
\hline \multirow{3}{*}{ o-Xylene } & Mean & $45 \pm 20$ & $11.6 \pm 1.2$ & $6.3 \pm 0.7$ & & $4.5 \pm 1.2$ & $3.3 \pm 0.4$ & $2.7 \pm 0.8$ & \\
\hline & Max & 70 & 12.7 & 7.1 & $21 \pm 9$ & 5.7 & 3.5 & 3.6 & $3.5 \pm 0.8$ \\
\hline & Min & 20 & 10.3 & 5.8 & & 3.4 & 2.8 & 2.1 & \\
\hline
\end{tabular}



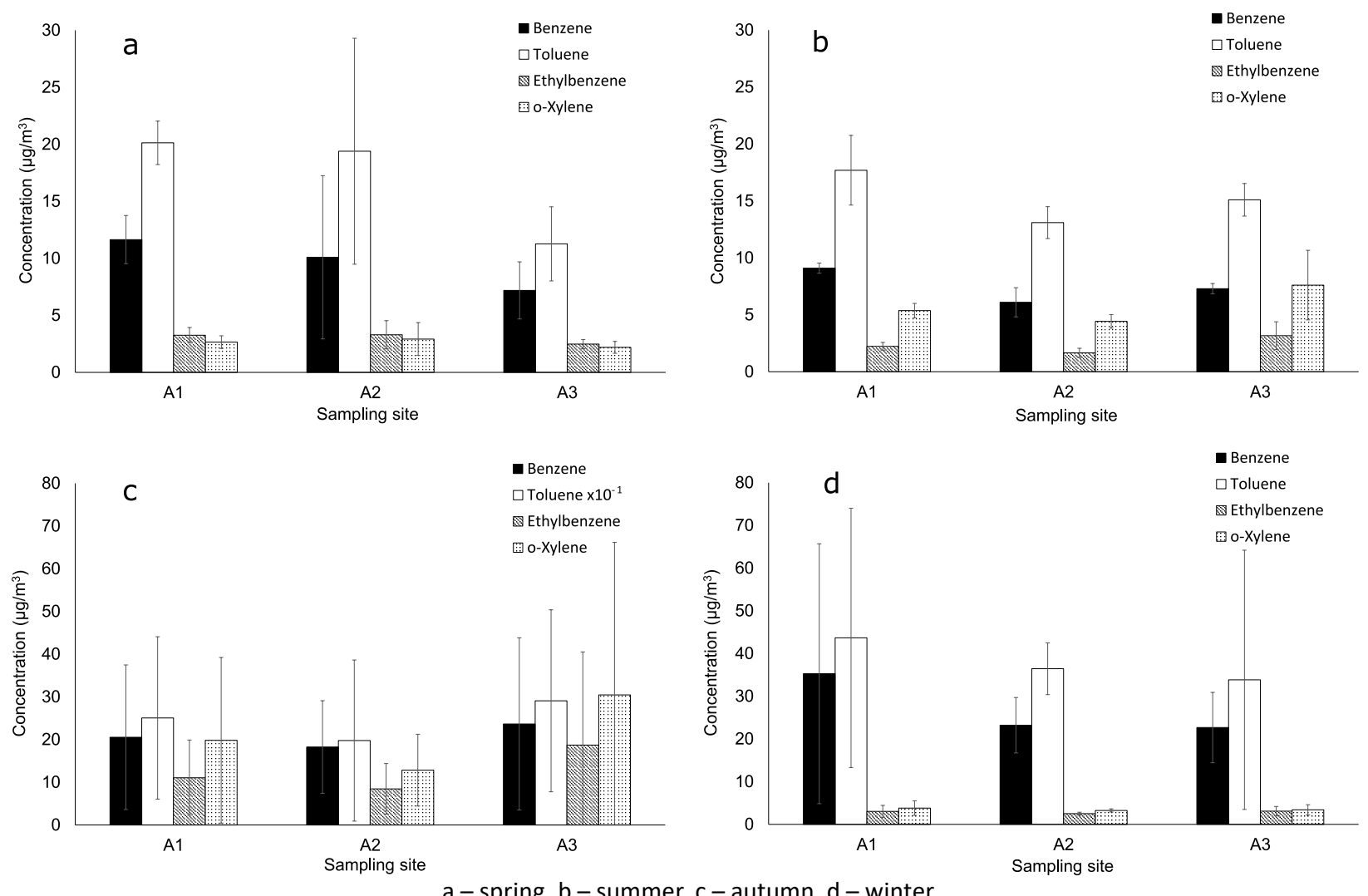

Figure 2 - Mean concentrations of BTEX at different districts of Taldykorgan

located in the eastern part of the city, almost on its suburb close to the Karatal River that provides air circulation (Table 1). In summer season, on the contrary, the lowest concentrations of BTEX were found in the Center, and the highest - in Karatal district. However, the most popular entertainment places are located in Karatal district, which results in an increased number of people and cars in the summer season.

In the $2^{\text {nd }}$ microdistrict, there is a "ring" of 5 roads, one of which is the Almaty highway with traffic jams and weak air circulation. Results of monitoring in autumn and winter seasons are similar to the ones in the summer. The minimum concentrations of BTEX were determined on Tuesday (April 10) and on Thursday (July 12), most probably, due to rain. Toluene/ benzene ( $T / B$ ) ratios were lower in Karatal district and higher in $2^{\text {nd }}$ microdistrict, but in both cases, $T / B$ ratios were higher than 1. During all sampling period, $T / B$ ratios were lower than 1 in 4 of 36 samples. Such ratios show that the main sources of BTEX originated from transport related sources [18].

\subsection{Seasonal variations}

Sampling of air and analyses were conducted during four seasons (Figure 3). Despite the three-month difference, the seasonal mean concentrations in spring and summer were similar: 9.6 and $7.5 \mu \mathrm{g} / \mathrm{m}^{3}$ for benzene, 16.9 and $15.3 \mu \mathrm{g} / \mathrm{m}^{3}$ for toluene, 3.0 and $2.4 \mu \mathrm{g} / \mathrm{m}^{3}$ for ethylbenzene, 2.6 and $5.8 \mu \mathrm{g} / \mathrm{m}^{3}$ for $o$-xylene, respectively.
A substantial difference was observed only in the concentration of $o$-xylene that can be caused by an increase in the number of cars in the summer season. Both seasons were characterized by abundant flowering of trees, flowers and other plants, which promotes photosynthesis purifying the air at the same time. A substantial concentration raise of all compounds was in autumn: 21, 250, 12.8 and $21 \mu \mathrm{g} / \mathrm{m}^{3}$, for BTEX, respectively. These changes could be caused by the beginning of the heating season in October, and also the burning of leaves in open areas. Another factor is the temperature decrease that results in slowing down air circulation. A particular increase in concentration was observed for toluene. Even in winter, the average concentration of toluene $\left(38 \mu \mathrm{g} / \mathrm{m}^{3}\right)$ was about six times lower than in autumn. The source of such high concentrations of toluene in autumn is impossible to explain using the available data. To answer this question, additional research is needed.

The maximum concentration of benzene $\left(27 \mu \mathrm{g} / \mathrm{m}^{3}\right)$ was detected in winter season. Mean concentrations of ethylbenzene $\left(2.9 \mu \mathrm{g} / \mathrm{m}^{3}\right)$ and $o$-xylene $\left(3.5 \mu \mathrm{g} / \mathrm{m}^{3}\right)$ were in the same range as in spring and summer. In most samples, concentrations of ethylbenzene and $o$-xylene were ten times lower than those of benzene and toluene (Tables 5 and 6), most probably, due to their lower stability in air [19], content in gasoline [20], exhaust gases of cars [21] and other emissions. 


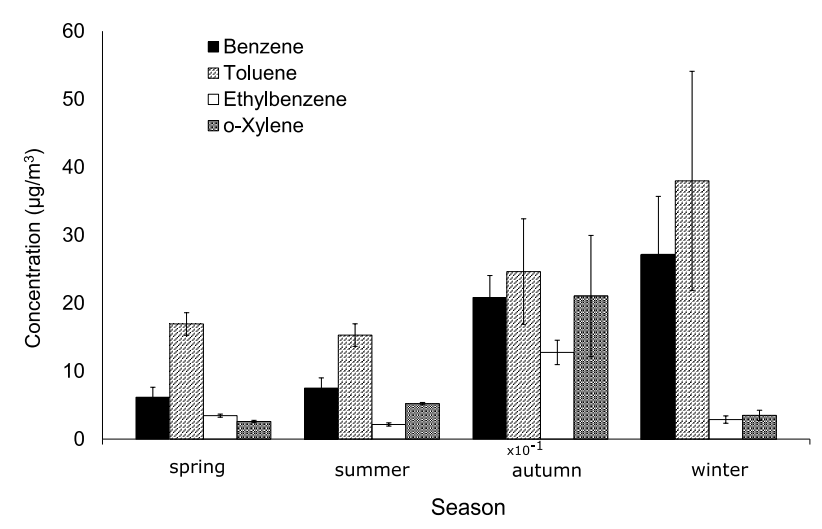

Figure 3 - Concentrations of BTEX in different seasons

Mean T/B ratio were in the range from 1.2 and 1.8 in all seasons except autumn, when T/B was 10.6 .

3.4 Comparison with other cities

In the middle of spring, concentrations of BTEX in air of Taldykorgan were compared with BTEX concentrations in Almaty, Kazakhstan (Figure 4). Mean concentrations of benzene

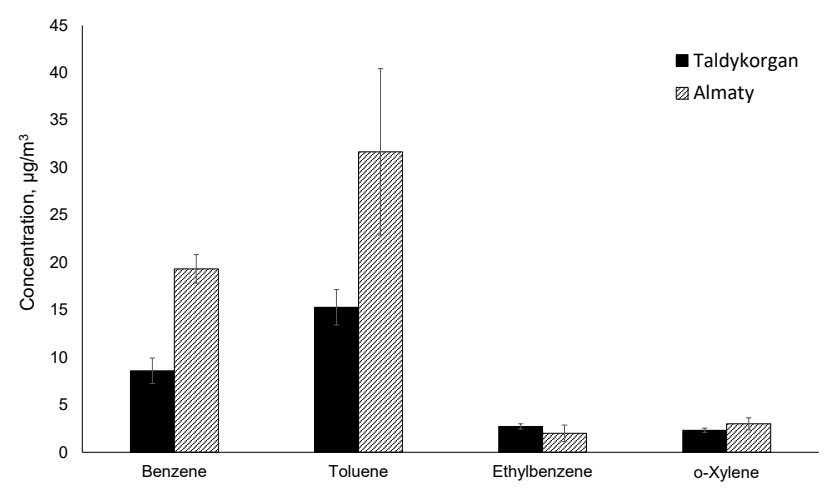

Figure 4 - Concentrations of BTEX in spring 2018 in air of Taldykorgan and Almaty and toluene in air collected in spring in Taldykorgan (10 and $17 \mu \mathrm{g} / \mathrm{m}^{3}$ ) were about two times lower than at the same season in Almaty (19 and $32 \mu \mathrm{g} / \mathrm{m}^{3}$ ). Concentrations of ethylbenzene and $o$-xylene in two cities ranged from 2 to $4 \mu \mathrm{g} / \mathrm{m}^{3}$. Mean concentrations of BTEX in air of Almaty were close to those in cities around the world with high levels of air pollution such as New Delhi, Cairo, Rome, Ho Chi Minh city, San-Paulo and Manila [17], while in Taldykorgan, BTEX concentrations were substantially lower, which indicates a lower level of air pollution with BTEX.

\section{Conclusions}

Thus, the monitoring of BTEX in ambient air of Taldykorgan, Kazakhstan was conducted for the first time. Highest concentrations of TEX were observed in autumn, except benzene, maximum concentrations of which were in winter. In Taldykorgan, T/B ratio were higher than 1 in most samples indicating the greatest contribution of transport-related sources of BTEX. Concentrations of benzene and toluene in spring in air of Taldykorgan were about two times lower than those in Almaty at the same period. The concentrations of ethylbenzene and $o$-xylene were similar in both cities. The obtained results prove that the method developed by Baimatova et al. [17] is efficient and can be applied for air monitoring in many other cities. The obtained results can be used for developing air pollution monitoring network in Taldykorgan. For better decision making, Taldykorgan can be compared to other cities using the partial order ranking methodology proposed by Carlsen et al. [22].

\section{Acknowledgments}

This research was funded by the Science Committee of the Ministry of Education and Science of the Republic of Kazakhstan (Grant No. AP05133158). Olga Ibragimova would like to thank the Ministry of Education and Science of Kazakhstan for supporting her study with a Ph.D. scholarship.

\section{References (GOST)}

1 World Health Organization. Ambient (outdoor) air quality and health - 2018. URL: http://www.who.int/news-room/factsheets/detail/ambient-(outdoor)-air-quality-and-health.

2 Atkinson J., Arey R. Atmospheric degradation of volatile organic compounds // Chemistry Review. - 2003. - Vol.103. - P.46054638.

3 Dales R., Liu L., Wheeler A., Gilbert N. Quality of indoor residential air and health // Canadian Medical Association. Journal. 2008. - Vol.179, Is.2. - P.147-152.

4 EPA Integrated Risk Information System (IRIS) on Benzene. National Center for Environmental Assessment, Office of Research and Development, Washington, DC 2009.

5 Krol S., Zabiegala B., Namiesnik J. Monitoring VOCs in atmospheric air II. Sample collection and preparation // TrAC - Trends in Analytical Chemistry. - 2010. - Vol.29, Is.9. - P.1101-1112.

6 Wang P., Zhao W. Assessment of ambient volatile organic compounds (VOCs) near major roads in urban Nanjing, China // Atmospheric Research. - 2008. - Vol.89. - P.289-297. 
7 Compendium Method TO-15 Determination of Volatile Organic Compounds (VOCs) In Air Collected In Specially Prepared Canisters and Analyzed By Gas Chromatography/Mass Spectrometry (GC/MS) // U.S. Environmental Protection Agency (EPA). 1999. - P.12.

8 Batterman S., Zhang G., Baumann M. Analysis and stability of aldehydes and terpenes in electropolished canisters // Atmospheric Environment. - 1998. - Is.32. - P.1647-1655.

9 Compendium Method TO-17 Determination of Volatile Organic Compounds in Ambient Air Using Active Sampling Onto Sorbent Tubes // U.S. Environmental Protection Agency (EPA). - U.S. Environmental Protection Agency (EPA), 1999. - 1-53 p.

10 GOST R ISO 16017-1-2007. Atmospheric air, the working area and enclosed spaces. Sampling of volatile organic compounds using a sorption tubes with subsequent thermal desorption and gas chromatographic analysis on capillary columns. - Moscow, Russia, 2007. - P.40. (In Russian)

11 Sanchez J., Sacks R. Performance characteristics of a new prototype for a portable GC using ambient air as carrier gas for onsite analysis // Journal of separation Science. - 2007. - Vol.30, Is.7. - P.1052-1060.

12 Feng C., Mitra S. Breakthrough and desorption characteristics of a microtrap // Journal of Microcolumn Separations. - 2000. - Vol.12, Is.4. - P.267-275.

13 Gong Y., Eom I., Lou D., Hein D., Pawliszyn J. Development and application of a needle trap device for time-weighted average diffusive sampling // Analytical Chemistry. - 2008. - Vol.80, Is.19. - P.7275-7282.

14 Elke K., Jermann E. Determination of benzene, toluene, ethylbenzene and xylenes in indoor air at environmental levels using diffusive samplers in combination with headspace solid-phase microextraction and high-resolution gas chromatography-flame ionization detection // Journal of Chromatography. - 1998. - Vol.826, Is.2. - P.191-200.

15 Khaled A., Pawliszyn J. Time-weighted average sampling of volatile and semi-volatile airborne organic compounds by the solidphase microextraction device // Journal of Chromatography A. - 2000. - Vol.892, Is.1-2. - P. 455-467.

16 Carlsen L., Kenessov B.N., Baimatova N.K., Kenessova O.A. Assessment of the Air Quality of Almaty . Focussing on the Traffic Component // International Journal of Biology and Chemistry. - 2013. - Vol.1(5). - P.49-69.

17 Baimatova N., Kenessov B., Koziel J.A., Carlsen L., Bektassov M., Demyanenko O.P. Simple and accurate quantification of BTEX in ambient air by SPME and GC-MS // Talanta. - 2016. - Vol.154. - P.46-52.

18 Liu K., Zhang C., Cheng Y., Liu C., Zhang H., Zhang G., Sun X., Mu Y. Serious BTEX pollution in rural area of the North China Plain during winter season // Journal of Environmental Sciences. - 2015. - Vol.30. - P.186-190.

19 Khoder M.I. Ambient levels of volatile organic compounds in the atmosphere of Greater Cairo // Atmospheric Environment. 2007. - Vol.41, Is.3. - P.554-566.

20 Gee I.L., Sollars C.J. Ambient air levels of volatile organic compounds in Latin American and Asian cities // Chemosphere. 1998. - Vol.36, Is.11. - P. 2497-2506.

21 Miller L., Xu X. Multi-season, multi-year concentrations and correlations amongst the BTEX group of VOCs in an urbanized industrial city // Atmospheric Environment. - 2012. - Vol.61. - P.305-315.

22 Carlsen L., Bruggemann R., Kenessov B. Use of partial order in environmental pollution studies demonstrated by urban BTEX air pollution in 20 major cities worldwide // Science of the Total Environment. - 2018. - Vol.610-611. - P.234-243.

\section{References}

1 (2018) World Health Organization. Ambient (outdoor) air quality and health. http://www.who.int/news-room/fact-sheets/ detail/ambient-(outdoor)-air-quality-and-health

2 Atkinson J, Arey R (2003) Chem Rev 103:4605-4638. http://doi.org/10.1021/cr0206420

3 Dales R, Liu L, Wheeler AJ, Gilbert NL (2008) Can Med Assoc J 179:147-152.

4 EPA (2009) Integrated Risk Information System (IRIS) on Benzene. National Center for Environmental Assessment, Office of Research and Development, Washington, DC.

5 Krol S, Zabiegala BNJ, Król S, Zabiegała B, Namieśnik J (2010) TrAC - Trends Anal Chem 29:1101-1112. http://doi.org/10.1016/j. trac.2010.05.010

6 Wang P, Zhao W (2008) Atmos Res 89:289-297.

7 Compendium Method TO-15 (1999) US Environ Prot Agency 12.

8 Batterman S, Zhang G, Baumann M (1998) Atmos Environ 1647-1655.

9 Compendium Method TO-17 (1999) Determination of Volatile Organic Compounds in Ambient Air Using Active Sampling Onto Sorbent Tubes. US Environmental Protection Agency (EPA).

10 (2007) GOST R ISO 16017-1-2007. Atmospheric air, the working area and enclosed spaces. Sampling of volatile organic compounds using a sorption tubes with subsequent thermal desorption and gas chromatographic analysis on capillary columns, Moscow, Russia. (In Russian)

11 Sanchez J, Sacks R (2007) J Sep Sci 30(7):1052-60. 
12 Feng C, Mitra S (2000) J Microcolumn Sep 12:267-275. http://doi.org/10.1002/(SICI)1520-667X(2000)12:4<267::AIDMCS11>3.0.CO;2-B

13 Gong Y, Eom IY, Lou DW, Hein D, Pawliszyn J (2008) Anal Chem 80:7275-7282. http://doi.org/10.1021/ac800884f

14 Elke K, Jermann E (1998) J Chromatogr 826:191-200. http://doi.org/10.1016/S0021-9673(98)00736-5

15 Khaled A, Pawliszyn J (2000) J Chromatogr A 892:455-467. http://doi.org/10.1016/S0021-9673(00)00295-8

16 Carlsen L, Kenessov BN, Baimatova NK, Kenessova OA (2013) Int J Biol Chem 1(5):49-69.

17 Baimatova N, Kenessov B, Koziel JA, Carlsen L, Bektassov M, Demyanenko OP (2016) Talanta 154:46-52. http://doi.org/10.1016/j. talanta.2016.03.050

18 Liu K, Zhang C, Cheng Y, Liu C, Zhang H, Zhang G, Sun X, Mu Y (2015) J Environ Sci 30:186-190. http://doi.org/10.1016/j. jes.2014.05.056

19 Khoder MI (2007) Atmos Environ 41:554-566. http://doi.org/10.1016/j.atmosenv.2006.08.051

20 Gee IL, Sollars CJ (1998) Chemosphere 36:2497-2506. http://doi.org/10.1016/S0045-6535(97)10217-X

21 Miller L, Xu X (2012) Atmos Environ 61:305-315. http://doi.org/10.1016/j.atmosenv.2012.07.041

22 Carlsen L, Bruggemann R, Kenessov B (2018) Sci Total Environ 610-611:234-243. http://doi.org/10.1016/j.scitotenv.2017.08.029 